\title{
KONFLIK PERIKANAN TANGKAP DI PERAIRAN KABUPATEN BENGKALIS PROVINSI RIAU
}

\author{
Fishing Conflict in The Waters of Bengkalis Regency Riau Province
}

Oleh:

\author{
T. Ersti Yulika Sari ${ }^{*}$, Sugeng H. Wisudo², Daniel R. Monintja², dan Tommy Purwaka ${ }^{3}$ \\ 1Jurusan Pemanfaatan Sumber Daya Perikanan, FPIK, UNRI, Jl. HR Subrantas km 12,5 Pekanbaru, Riau 28293 \\ ${ }^{2}$ Departemen Pemanfaatan Sumber Daya Perikanan, FPIK, IPB, Jl. Lingkar Kampus, Darmaga - Bogor 16680 \\ ${ }_{3}^{3}$ Universitas Kristen Indonesia, Jl. Mayjen Sutoyo 2, Cawang, Jakarta 13630 \\ * Korespondensi: nonnysaleh@hotmail.com
}

Diterima: 14 Januari 2010; Disetujui: 10 Maret 2010

\begin{abstract}
The purpose of this study is to analyze the conflict in Bengkalis waters and contributing factors. Analysis of the conflict is descriptive and the factors that cause conflict with the approach of analyzed Fisher et al. (2000). The study was conducted in the waters Bengkalis Regency. The results showed that the conflict in Bengkalis waters began in 1983 to the present. This conflict started when hunting for kurau (Eleutheronema tetradactylum) in the waters of District Bantan began to rise. Primary factors driving the conflict has not received much attention and as basis for conflict resolution that remains in progress. These factors are identified into three parts: 1) cultural background, 2) social factors, and 3) juridical factor.
\end{abstract}

Key words: Bengkalis Regency, conflict, kurau (Eleutheronema tetradactylum)

\section{ABSTRAK}

Tujuan penelitian ini adalah menganalisis konflik yang terjadi di perairan Bengkalis dan faktor-faktor penyebabnya. Konflik dianalisis secara deskriptif, sedangkan faktor-faktor penyebab konflik dianalisis dengan pendekatan Fisher et al. (2000). Penelitian dilakukan di perairan Kabupaten Bengkalis. Hasil penelitian menunjukkan bahwa konflik terjadi pada tahun 1983 hingga saat ini. Hal ini dimulai pada saat perburuan terhadap ikan kurau (Eleutheronema tetradactylum) mulai meningkat di perairan ini. Faktor mendasar pendorong terjadinya konflik belum banyak mendapat perhatian dan belum dijadikan dasar dalam penyelesaiannya sehingga konflik tetap berlangsung. Faktor tersebut diidentifikasi menjadi tiga bagian: 1) dilatarbelakangi kultur nelayan rawai Kecamatan, 2) faktor sosial dan 3) faktor yuridis.

Kata kunci: Kabupaten Bengkalis, konflik, kurau (Eleutheronema tetradactylum)

\section{PENDAHULUAN}

Konflik yang terjadi antara nelayan rawai, nelayan jaring batu dan nelayan trawl yang beroperasi di Perairan Provinsi Riau merupakan peristiwa yang sering terjadi di wilayah Pantai Timur Sumatera. Konflik dengan nelayan rawai disebabkan pengusaha perikanan jaring batu dan trawl menangkap ikan pada jalur penangkapan nelayan rawai, yaitu diba- wah 3 mil laut dari garis pantai. Nelayan rawai mengalami penurunan hasil tangkapan, sebagai akibat ketidakmampuan untuk bersaing dengan nelayan jaring batu (bottom drift gillnet) ataupun nelayan trawl. Kondisi ini menyebabkan nelayan rawai mengadakan perlawanan dengan melakukan pembakaran dan penyanderaan terhadap beberapa kapal jaring batu dan trawl. Konflik pemanfaatan sumber daya perikanan di kawasan ini telah muncul sejak tahun 
1980-an yang pada umumnya disebabkan oleh adanya introduksi teknologi dengan dalih modernisasi. Modernisasi pada berbagai sektor telah banyak menciptakan masalah, ketimpangan dan ketidakadilan dalam pemanfaatan sumber daya alam.

Modernisasi yang terjadi pada perikanan tangkap telah memperbesar intensitas upaya eksploitasi terhadap sumber daya perikanan di Perairan Kecamatan Bantan yang mengakibatkan terganggunya sistem sosial masyarakat setempat. Hal ini berakibat terancamnya mata pencaharian dan sistem nilai yang berlaku di tengah masyarakat. Keadaan ini memperpanjang daftar kasus konflik antara nelayan rawai Kecamatan Bantan dengan nelayan jaring batu yang dikuasai oleh para pemodal yang dirasakan semakin berkembang secara tajam. Hingga saat ini belum tampak adanya indikasi akan berakhirnya konflik dan dilakukannya upaya damai dari kedua belah pihak. Upaya penyelesaian konflik telah banyak dilakukan, tetapi sampai sejauh ini hasilnya masih kurang memuaskan bagi pihak yang berkonflik. Salah satunya disebabkan oleh belum dikenalinya tipologi konflik yang terjadi.

Tujuan penelitian ini adalah menganalisis konflik yang terjadi di perairan Bengkalis dan mengetahui faktor-faktor penyebab terjadinya konflik.

\section{METODE PENELITIAN}

\section{Pengumpulan Data}

Pengumpulan data dilakukan dengan menggunakan kuesioner terstruktur yang ditujukan untuk mengetahui jenis konflik dan faktor-faktor penyebab konflik. Data pendukung diperoleh melalui Kantor Kepala Desa, Kantor Camat Kecamatan Bantan, Dinas Perikanan dan Kelautan Kabupaten Bengkalis, Kantor Bagian Proyek Pembangunan Masyarakat Pantai dan Penggelolaan Sumber daya Perikanan (Co-Fish Project) Bengkalis dan Dinas Perikanan Provinsi Riau. Kajian terhadap berbagai dokumen atau kepusta-kaan yang relevan dilakukan untuk melengkapi dan mendukung hasil penelitian.

\section{Analisis Data}

Analisis konflik yang terjadi dilakukan secara deskriptif dan faktor-faktor penyebab konflik dianalisis dengan pendekatan Fisher et al. (2000). Tahapan analisis adalah:

1) Pentahapan konflik, bertujuan untuk melihat tahap-tahap dan siklus peningkatan dan penurunan konflik, serta membahas pada tahap mana situasi konflik saat ini.

2) Urutan kejadian, yang bertujuan untuk mengi- dentifikasi kejadian-kejadian yang paling penting untuk masing-masing pihak.

3) Pemetaan konflik, bertujuan untuk melihat hubungan antara berbagai pihak secara lebih jelas.

4) Analogi bawang bombay, bertujuan untuk menganalisis perbedaan pandangan tentang konflik dari pihak-pihak yang berkonflik.

\section{HASIL DAN PEMBAHASAN}

\section{Pentahapan dan Urutan Kejadian Konflik}

\section{Pentahapan konflik}

Konflik antara nelayan rawai dengan nelayan jaring kurau memiliki kedinamisan yang tinggi. Konflik berkembang sesuai dengan intensitas dan skala serta lamanya periode konflik. Data lapangan menunjukkan bahwa konflik semakin terbuka dengan munculnya perilakuperilaku yang kontra produktif (saling bertentangan) diantara pelaku konflik. Pentahapan konflik dalam penelitian ini merujuk pada Fisher et al. (2000) yang membagi lima tahapan konflik yaitu prakonflik, konfrontasi, krisis, akibat dan pascakonflik. Berdasarkan pendapat diatas, analisa pentahapan konflik pada tulisan ini digambarkan dalam grafik eskalasi konflik pada Gambar 1.

Kondisi krisis ini akibat dari semakin mengentalnya pertentangan antara pesengketa dan semakin merenggangnya hubungan antar pihak yang terlibat dalam pemanfaatan sumber daya di perairan Bengkalis. Walaupun terjadi penurunan aktifitas yang konfrontatif, tetapi tidak menunjukkan gejala akan berakhir. Hal tersebut merupakan peredaman sementara yang dilakukan oleh pesengketa sendiri maupun oleh pihak lain.

Bentuk-bentuk konflik pemanfaatan sumberdaya perikanan yang terjadi di perairan Bengkalis antara lain:

1. Perkelahian di laut tahun 1983 antara nelayan rawai dengan nelayan jaring kurau.

2. Perusakan alat tangkap rawai oleh nelayan jaring batu tahun 1985, 1986 dan 1988.

3. Penangkapan kapal jaring batu tahun 1990, 1997, 1998 dan 1999.

4. Penangkapan kapal dan pembakaran jaring batu tahun 1999.

5. Tuntutan ganti rugi nelayan rawai tahun 2000.

6. Pembakaran kapal jaring batu tahun 1998, 2001 dan 2002.

7. Pemanahan dan aksi saling sandera tahun 2003.

8. Demontrasi dan tuntutan nelayan rawai tahun 2004 dan 2005. 


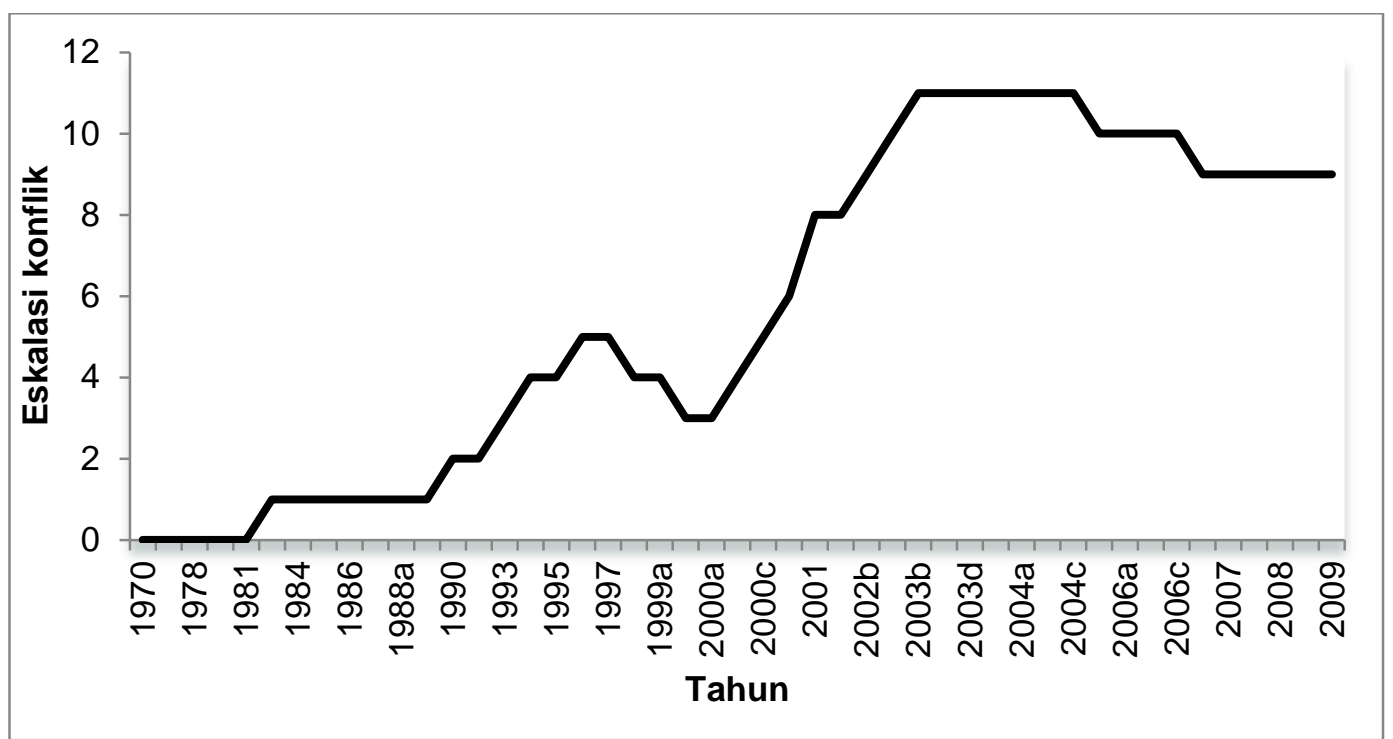

Gambar 1 Grafik penahapan terjadinya konflik antara nelayan rawai dengan nelayan jaring kurau berdasarkan Fisher et al 2000.

9. Pembakaran, penculikan dan penangkapan terhadap nelayan rawai, tahun 2006.

10.Aksi massa dan tuntutan nelayan yang tergabung dalam SNKB, tahun 2008.

Konflik antara nelayan rawai dengan nelayan jaring batu di perairan Kecamatan Bantan sudah berlangsung hampir tiga dasawarsa. Konflik berkepanjangan ini berawal ketika perburuan terhadap spesies ikan kurau di kawasan perairan Kecamatan Bantan mulai meningkat.

Perburuan terhadap ikan kurau (Eleutheronema tetradactylum) mulai intensif dilakukan pada tahun 1981 oleh nelayan kapal motor dengan mengunakan alat tangkap jaring batu. Masyarakat nelayan Kecamatan Bantan masih menggunakan sampan dayung dan alat tangkap rawai. Tercatat pada tahun yang sama tidak kurang dari 40 unit kapal jaring batu beroperasi di wilayah tangkap nelayan rawai di perairan Kecamatan Bantan. Maraknya perburuan ikan kurau menyebabkan banyak nelayan jaring batu masuk ke perairan Kecamatan Bantan untuk menguasai daerah tangkapan nelayan rawai. Masuknya alat tangkap ini membuat kenyamanan nelayan Kecamatan Bantan terganggu sehingga terjadi banyak pertikaian di laut sebagai bentuk penolakan nelayan rawai.

Pertikaian-pertikaian tersebut mulanya dipicu oleh pelanggaran-pelanggaran yang dilakukan nelayan jaring batu terhadap nelayan rawai seperti kapal jaring batu menabrak nelayan rawai atau mengusir nelayan rawai supaya nelayan jaring batu bebas melakukan penangkapan. Selain pelanggaran yang menimbulkan kerugian langsung pada nelayan rawai, nelayan jaring batu juga dianggap telah melanggar nilai-nilai yang berlaku di wilayah tangkapan nelayan rawai.
Formulasi data lapangan terhadap latar belakang konflik ditampilkan dalam bentuk urutan kejadian untuk menunjukkan sejarah konflik berdasarkan tahun, bulan dan tanggal sesuai dengan skalanya. Urutan kejadian konflik nelayan rawai Kecamatan Bantan dengan jaring batu dari tahun 1970-an sampai tahun 2004 disajikan pada Tabel 1.

\section{Pemetaan Konflik}

Fisher et al. (2000), menyatakan bahwa pemetaan konflik merupakan suatu cara untuk menggambarkan konflik secara grafis, menghubungkan pihak-pihak dengan masalah dan pihak lainnya. Pihak-pihak yang terlibat baik langsung maupun tidak langsung pada konflik ini divisualkan kedalam peta konflik yang disajikan pada Gambar 2.

Hubungan keterlibatan antara masingmasing pihak dinyatakan pula dalam peta konflik. Pihak yang berkonflik adalah nelayan rawai yang berasal dari Kecamatan Bantan yaitu antara nelayan rawai dan nelayan jaring batu yang dimodali tauke (pengusaha) yang berasal dari dalam dan luar Propinsi Riau.

Situasi yang tidak harmonis antara pihak yang berkonflik (Gambar 2) karena adanya perbedaan nilai dan cara pandang terhadap sumberdaya perikanan, sehingga masing-masing pesengketa memiliki metode yang berbeda dalam pemanfaatan sumber daya perikanan. Sejalan dengan itu, terdapat perbedaan kepentingan yang bertolak belakang antara kedua belah pihak, termasuk tingkat ketergantungan terhadap sumber daya perikanan. Pemerintah sebagai pembuat kebijakan dalam regulasi sektor perikanan akan sangat berperan dalam situasi ini. 
Tabel 1 Urutan kejadian konflik nelayan rawai dengan jaring batu

\begin{tabular}{|c|c|c|c|}
\hline WAKTU & BENTUK KONFLIK & SKALA DAN INTENSITAS & LOKASI \\
\hline $\begin{array}{l}1970 \\
s / d\end{array}$ & \multirow[t]{2}{*}{$\begin{array}{l}\text { Nelayan rawai menangkap ikan } \\
\text { kurau dengan rawai } \\
\text { mengunakan sampan dayung }\end{array}$} & \multirow[t]{2}{*}{-} & \multirow[t]{2}{*}{-} \\
\hline 1979 & & & \\
\hline 1981 & $\begin{array}{l}\text { Pemburuan terhadap ikan } \\
\text { kurau melalui intensif dilakukan } \\
\text { oleh jaring batu/kurau yang } \\
\text { mengunakan kapal motor. }\end{array}$ & - & - \\
\hline \multirow[t]{3}{*}{1983} & \multirow{3}{*}{$\begin{array}{l}\text { Perkelahian nelayan jaring batu } \\
\text { dengan nelayan rawai di laut. }\end{array}$} & Jaring batu menabrak rawai & \multirow{3}{*}{$\begin{array}{l}\text { Teluk } \\
\text { Pambang }\end{array}$} \\
\hline & & $\begin{array}{l}\text { Nelayan rawai mendapat intimidasi aparat } \\
\text { yang membeking pemodal jaring batu }\end{array}$ & \\
\hline & & $\begin{array}{l}\text { Karena ketakutan masyarakat melarikan } \\
\text { diri ke Malaysia }\end{array}$ & \\
\hline 1984 & $\begin{array}{l}\text { Nelayan jaring batu leluasa } \\
\text { beroperasi di perairan Bantan } \\
\text { tanpa ada perlawanan dari } \\
\text { nelayan rawai }\end{array}$ & - & - \\
\hline 1985 & $\begin{array}{l}\text { Dinas Perikanan melakukan } \\
\text { penangkapan satu unit kapal } \\
\text { motor jaring batu }\end{array}$ & $\begin{array}{l}\text { Jaring batu beroperasi di wilayah 0-3 mil } \\
\text { dan menabrak rawai. }\end{array}$ & $\begin{array}{l}\text { Teluk } \\
\text { Pambang }\end{array}$ \\
\hline 1986 & $\begin{array}{l}\text { Penangkapan satu unit jaring } \\
\text { batu oleh nelayan rawai dan } \\
\text { dibawa ke pantai Desa Teluk } \\
\text { Pambang }\end{array}$ & Jaring batu menabrak rawai & $\begin{array}{l}\text { Teluk } \\
\text { Pambang }\end{array}$ \\
\hline 1987 & $\begin{array}{l}\text { Bentrokan nelayan rawai } \\
\text { dengan nelayan jaring batu }\end{array}$ & Nelayan jaring batu menabrak rawai & $\begin{array}{l}\text { Teluk } \\
\text { Pambang }\end{array}$ \\
\hline 1988 & Bentrokan di laut & Nelayan jaring batu menabrak rawai & $\begin{array}{l}\text { Teluk } \\
\text { Pambang }\end{array}$ \\
\hline 1988 & Bentrokan di laut & $\begin{array}{l}\text { Nelayan jaring batu menabrak dan } \\
\text { merusak rawai, nelayan rawai membalas } \\
\text { dengan memotong pelampung jaring batu }\end{array}$ & $\begin{array}{l}\text { Teluk } \\
\text { Pambang }\end{array}$ \\
\hline 1990 & Terjadi bentrokan & Nelayan jaring batu menabrak rawai & $\begin{array}{l}\text { Teluk } \\
\text { Pambang }\end{array}$ \\
\hline 1991 & $\begin{array}{l}\text { Terjadi penangkapan jaring } \\
\text { batu }\end{array}$ & $\begin{array}{l}\text { Beroperasi di kawasan tangkap nelayan } \\
\text { rawai }\end{array}$ & $\begin{array}{l}\text { Teluk } \\
\text { Pambang }\end{array}$ \\
\hline \multirow[t]{2}{*}{1993} & \multirow[t]{3}{*}{ Bentrok terjadi di laut } & Jaring batu menabrak dan merusak rawai & \multirow{2}{*}{$\begin{array}{l}\text { Teluk } \\
\text { Pambang }\end{array}$} \\
\hline & & $\begin{array}{l}\text { Tindakan tersebut dibalas oleh nelayan } \\
\text { rawai dengan mengiris tali jaring batu dan } \\
\text { ditinggal lari }\end{array}$ & \\
\hline 1994 & & Melayan jaring batu menabrak rawai & $\begin{array}{l}\text { Teluk } \\
\text { Pambang }\end{array}$ \\
\hline 1995 & $\begin{array}{l}\text { Dinas Perikanan Bengkalis, } \\
\text { Camat Bantan, Kades Desa } \\
\text { Teluk Pambang melakukan } \\
\text { patroli }\end{array}$ & $\begin{array}{l}\text { Tiga unit kapal jaring batu ditangkap } \\
\text { karena melanggar perjanjian yang telah } \\
\text { dibuat sebelumnya }\end{array}$ & $\begin{array}{l}\text { Teluk } \\
\text { Pambang }\end{array}$ \\
\hline 1996 & Bentrok diperairan laut & Jaring batu menabrak rawai & $\begin{array}{l}\text { Teluk } \\
\text { Pambang }\end{array}$ \\
\hline 1997 & $\begin{array}{l}\text { Nelayan rawai melakukan } \\
\text { ronda laut }\end{array}$ & Mengangkap dua unit kapal jaring batu & $\begin{array}{l}\text { Teluk } \\
\text { Pambang }\end{array}$ \\
\hline 7 Juli 1998 & $\begin{array}{l}\text { Masyarakat menangkap jaring } \\
\text { batu lalu di bawa ke pantai }\end{array}$ & Tiga unit jaring batu dibakar di pantai & $\begin{array}{l}\text { Teluk } \\
\text { Pambang }\end{array}$ \\
\hline
\end{tabular}




\begin{tabular}{|c|c|c|c|}
\hline 8 Juli 1999 & $\begin{array}{l}\text { Masyarakat Desa Teluk } \\
\text { Pambang mengadakan } \\
\text { penangkapan kapal jaring batu } \\
\text { yang beroperasi di perairan } \\
\text { Teluk Pambang }\end{array}$ & $\begin{array}{l}\text { Tiga unit kapal jaring batu di bawa ke } \\
\text { pantai }\end{array}$ & $\begin{array}{l}\text { Teluk } \\
\text { Pambang }\end{array}$ \\
\hline 20 Juli 1999 & $\begin{array}{l}\text { Terjadi penangkapan kapal } \\
\text { jaring batu di antara Perairan } \\
\text { Bantan Air dan Muntai }\end{array}$ & Jaring dibakar dan kapal ditarik kepantai & Bantan Air \\
\hline 29 Jan 2000 & $\begin{array}{l}\text { Masyarakat Desa Teluk } \\
\text { Pambang melakukan } \\
\text { penangkapan kapal jaring batu }\end{array}$ & $\begin{array}{l}\text { Dua kapal jaring batu tertangkap dan } \\
\text { dibawa ke pantai }\end{array}$ & $\begin{array}{l}\text { Teluk } \\
\text { Pambang }\end{array}$ \\
\hline 12 Feb 2000 & $\begin{array}{l}\text { Masyarakat Desa Selat Baru } \\
\text { melakukan penangkapan }\end{array}$ & $\begin{array}{l}\text { Satu kapal jaring batu di tahan } \\
\text { masyarakat }\end{array}$ & Selat Baru \\
\hline 18 Mai 2000 & $\begin{array}{l}\text { Nelayan Desa Selat Baru dan } \\
\text { Desa Teluk Pambang yang } \\
\text { tergabung dalam SNKB } \\
\text { (Serikat Nelayan Kabupaten } \\
\text { Bengkalis) melakukan } \\
\text { penangkapan }\end{array}$ & Lima unit kapal jaring batu tertangkap & $\begin{array}{l}\text { Teluk } \\
\text { Pambang }\end{array}$ \\
\hline 9 Sep 2000 & $\begin{array}{l}\text { Nelayan yang tergabung dalam } \\
\text { SNKB melakukan penagkapan } \\
\text { kembali }\end{array}$ & $\begin{array}{l}\text { Dua unit kapal jaring batu ditahan oleh } \\
\text { SNKB (Serikat Nelayan Kabupaten } \\
\text { Bengkalis) }\end{array}$ & Jangkang \\
\hline 25 Feb 2001 & $\begin{array}{l}\text { SNKB melakukan } \\
\text { penangkapan kapal jaring batu } \\
\text { di perairan Teluk Pambang }\end{array}$ & Satu unit jaring batu ditahan & $\begin{array}{l}\text { Teluk } \\
\text { Pambang }\end{array}$ \\
\hline 1 Juni 2001 & $\begin{array}{l}\text { SNKB melakukan } \\
\text { penangkapan jaring batu di } \\
\text { perairan Teluk Pambang. }\end{array}$ & $\begin{array}{l}\text { Tiga unit kapal jaring batu yang berasal } \\
\text { dari Kec. Merbau berhasil ditangkap. Satu } \\
\text { unit dibakar ditengah laut. Dan dua unit } \\
\text { lainnya di bawa kepantai. }\end{array}$ & $\begin{array}{l}\text { Teluk } \\
\text { Pambang }\end{array}$ \\
\hline 29 Apr 2002 & $\begin{array}{l}\text { Pembakaran kapal jaring batu } \\
\text { yang melakukan penangkapan } \\
\text { ikan di Perairan Jangkang di } \\
\text { bawah } 4 \text { mil laut }\end{array}$ & $\begin{array}{l}2 \text { unit kapal jaring batu dibakar oleh } \\
\text { masyarakat jangkang }\end{array}$ & Jangkang \\
\hline 20 Okt 2002 & $\begin{array}{l}\text { SNKB kembali menangkap } \\
\text { kapal jaring batu di perairan } \\
\text { Teluk Pambang }\end{array}$ & $\begin{array}{l}\text { Satu unit kapal jaring batu tertangkap dan } \\
\text { dibawa ke pantai. }\end{array}$ & $\begin{array}{l}\text { Teluk } \\
\text { Pambang }\end{array}$ \\
\hline 6 Jan 2003 & $\begin{array}{l}\text { Nelayan jaring batu melakukan } \\
\text { penyerangan kepada nelayan } \\
\text { rawai }\end{array}$ & $\begin{array}{l}\text { Nelayan rawai mengalami luka dibagian } \\
\text { kepala dengan } 17 \text { jahitan karena dipukul } \\
\text { dengan besi oleh nelayan jaring batu }\end{array}$ & $\begin{array}{l}\text { Teluk } \\
\text { Pambang }\end{array}$ \\
\hline 1 Mar 2003 & $\begin{array}{l}\text { Nelayan jaring batu melakukan } \\
\text { penyanderaan ponpong } \\
\text { nelayan rawai }\end{array}$ & $\begin{array}{l}\text { Satu unit pompong nelayan rawai } \\
\text { disandera oleh nelayan jaring batu }\end{array}$ & $\begin{array}{l}\text { Teluk } \\
\text { Pambang }\end{array}$ \\
\hline \multirow[t]{4}{*}{16 Juni 2003} & \multirow{4}{*}{$\begin{array}{l}\text { Perang terbuka antara nelayan } \\
\text { rawai dengan nelayan jaring } \\
\text { batu }\end{array}$} & $\begin{array}{l}\text { Satu orang nelayan rawai cedera terkena } \\
\text { panah nelayan jaring batu }\end{array}$ & $\begin{array}{l}\text { Teluk } \\
\text { Pambang }\end{array}$ \\
\hline & & $\begin{array}{l}\text { Tiga Orang nelayan rawai disandra } \\
\text { nelayan jaring batu }\end{array}$ & \\
\hline & & $\begin{array}{l}\text { Enam orang nelayan jaring batu } \\
\text { disandera oleh nelayan rawai }\end{array}$ & \\
\hline & & $\begin{array}{l}\text { Satu unit pompong nelayan rawai di } \\
\text { sandera nelayan jaring batu, dan } 1 \text { unit } \\
\text { kapal jaring batu disandera oleh nelayan } \\
\text { rawai }\end{array}$ & \\
\hline 3 Juli 2003 & $\begin{array}{l}\text { Penyanderaan nelayan Desa } \\
\text { Kembung Luar oleh nelayan } \\
\text { jaring batu }\end{array}$ & $\begin{array}{l}\text { Dua orang nelayan kembung luar beserta } \\
1 \text { unit pompong disandera oleh nelayan } \\
\text { jaring batu }\end{array}$ & $\begin{array}{l}\text { Teluk } \\
\text { Pambang }\end{array}$ \\
\hline
\end{tabular}




\begin{tabular}{|c|c|c|c|}
\hline Akhir 2003 & $\begin{array}{l}\text { Terjadi penangkapan kapal } \\
\text { jaring batu di antara perairan } \\
\text { Desa Jangkang dan Selat Baru }\end{array}$ & Dua unit di bakar & Selat Baru \\
\hline 8 Jan 2004 & $\begin{array}{l}\text { Penangkapan jaring batu oleh } \\
\text { masyarakat Selat Baru }\end{array}$ & $\begin{array}{l}\text { Dua unit kapal jaring batu ditahan } \\
\text { masyarakat }\end{array}$ & Selat Baru \\
\hline Peb 2004 & $\begin{array}{l}\text { Penyanderaan warga Teluk } \\
\text { Pambang oleh nelayan jaring } \\
\text { batu }\end{array}$ & $\begin{array}{l}\text { Satu orang warga yang pulang } \\
\text { berdagang dari malaysia disandera } \\
\text { selama } 2 \text { hari }\end{array}$ & Rangsang \\
\hline \multirow[t]{2}{*}{ Juli 2004} & \multirow{2}{*}{$\begin{array}{l}\text { Penangkapan jaring batu yang } \\
\text { beroperasi dibawah } 4 \text { mil oleh } \\
\text { SNKB (dimotori oleh } \\
\text { masyarakat Selat Baru) } \\
\text { bersama Aparat Kepolisian } \\
\text { Bengkalis dan Sekcam Bantan }\end{array}$} & $\begin{array}{l}\text { Satu Unit jaring batu diamankan aparat, } 1 \\
\text { orang nelayan jaring batu (jang karim) di } \\
\text { proses serta } 1 \text { orang nelayan Selat Baru } \\
\text { di tahan (tuduhan penganiayaan) }\end{array}$ & \multirow[t]{2}{*}{ Selat Baru } \\
\hline & & $\begin{array}{l}\text { Kejadian ini berbuntut Aksi demo Nelayan } \\
\text { Rawai ke DPRD Bengkalis. }\end{array}$ & \\
\hline 8 Agt 2004 & $\begin{array}{l}\text { Penangkapan jaring batu oleh } \\
\text { SNKB }\end{array}$ & $\begin{array}{l}\text { Satu unit jaring batu ditahan dan ABK } \\
\text { kapal jaring batu dianiaya nelayan Rawai. } \\
\text { (dari keterangan SNKB, masyarakat } \\
\text { melampiaskan emosinya karena } \\
\text { penangkapan Jang Karim yang dianggap } \\
\text { gembong jaring batu pada beberapa hari } \\
\text { sebelumnya tidak mendapat sanksi apa- } \\
\text { apa dari kepolisian) }\end{array}$ & $\begin{array}{l}\text { Teluk } \\
\text { Pambang }\end{array}$ \\
\hline Okt 2005 & - & $\begin{array}{l}\text { DPRD Riau menyurati Danlanal, } \\
\text { Guskanlamabar dan KASAL, untuk } \\
\text { membantu penyelesaian masalah yang } \\
\text { melibatkan kesatuan }\end{array}$ & Pekanbaru \\
\hline 2006 & - & $\begin{array}{l}\text { Dikeluarkannya SK Gubernur Riau No } 17 \\
\text { tahun 2006, tentang pelarangan } \\
\text { pengoperasian jaring batu di Perairan } \\
\text { Bengkalis hingga } 12 \text { mil laut }\end{array}$ & Pekanbaru \\
\hline $\begin{array}{l}\text { 15-16 Juni } \\
2006\end{array}$ & $\begin{array}{l}\text { Nelayan jaring batu membakar } \\
1 \text { buah pompong rawai }\end{array}$ & $\begin{array}{l}\text { - Sepuluh orang nelayan rawai terluka } \\
\text { - } \quad \text { Polisi menangkap beberapa orang } \\
\text { nelayan rawai yang dituduh } \\
\text { membunuh nelayan jaring batu }\end{array}$ & $\begin{array}{l}\text { Teluk } \\
\text { Pambang } \\
\text { dan Ransang } \\
\text { Barat }\end{array}$ \\
\hline 16 Nov 2006 & $\begin{array}{l}\text { Terjadi penculikan di laut oleh } \\
\text { nelayan jaring batu }\end{array}$ & $\begin{array}{l}\text { Empat orang nelayan rawai hilang di } \\
\text { perairan Selat Malaka dan belum kembali } \\
\text { hingga saat ini }\end{array}$ & $\begin{array}{l}\text { Teluk } \\
\text { Pambang }\end{array}$ \\
\hline 2 April 2008 & $\begin{array}{l}\text { Nelayan yang tergabung } \\
\text { dakam SNKB ( } 1500 \text { orang) } \\
\text { melakukan aksi massa ke } \\
\text { Kantor Bupati Bengkalis }\end{array}$ & $\begin{array}{l}\text { Mendesak Pemkab Bengkalis dan } \\
\text { Pemprov Riau untuk membuat Perda } \\
\text { dengan segera atas SK Gubernur No } 17 \\
\text { tahun } 2006\end{array}$ & $\begin{array}{l}\text { Kabupaten } \\
\text { Bengkalis }\end{array}$ \\
\hline April 2008 & - & $\begin{array}{l}\text { Dibentuknya mediasi dalam penyelesaian } \\
\text { konflik antara nelayan rawai dengan jaring } \\
\text { batu }\end{array}$ & $\begin{array}{l}\text { Teluk } \\
\text { Pambang }\end{array}$ \\
\hline
\end{tabular}

Sumber: diolah dari data primer (wawancara) dan data sekunder (Yayasan Laksana Samudera; Cofish Project, Harian Pagi Riau Pos, Mingguan SEBATI, Edisi 16/Tahun I/ 3-9 Juli 2003, WALHI Riau dan berbagai sumber).

Kecurigaan nelayan rawai muncul akibat sikap yang tidak tegas aparat dalam menangani kasus-kasus yang terjadi, seperti melepaskan nelayan jaring batu yang tertangkap tanpa ada proses yang jelas. Sering kali kapal jaring batu yang ditangkap tidak dilengkapi IUP (izin usaha perikanan) atau SPI (surat penangkapan ikan) ganda. Charles (2001) menyatakan bahwa konflik merupakan gangguan sosial karena nelayan merasa tidak aman dalam melakukan kegiatan usahanya. Berdasarkan informasi dari nelayan, konflik antar nelayan juga terjadi akibat ketidakjelasan kebijakan yang telah dibuat oleh instansi terkait. Status dan frekuensi konflik perlu ditangani dengan cara implementasi hukum maupun ketegasan aparat terhadap pelanggaran 


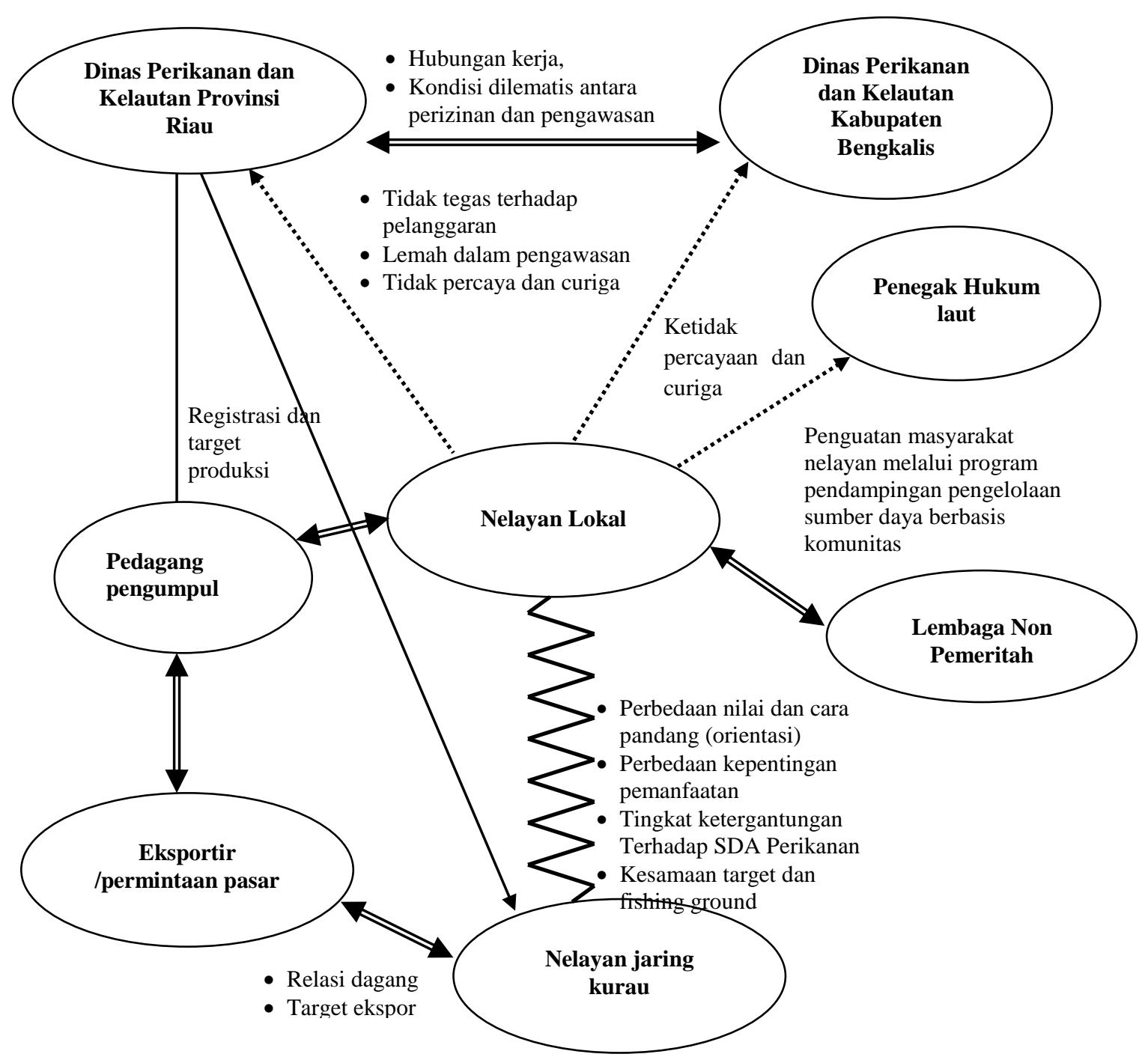

Keterangan:

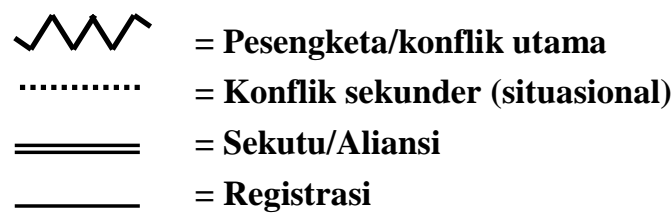

Gambar 2 Peta konflik nelayan di Perairan Bengkalis pada saat krisis

yang terjadi dengan melibatkan partisipasi masyarakat lokal. Hal ini sesuai dengan paradigma pengelolaan sumber daya perikanan berkelanjutan yaitu konservasi, rasional dan komunitas nelayan.

\section{Faktor-Faktor Penyebab Terjadinya Konflik}

Faktor mendasar pendorong terjadinya konflik belum banyak mendapat perhatian dan dijadikan dasar dalam penyelesaiannya. Faktor tersebut diidentifikasi menjadi tiga bagian: 1) dilatarbelakangi kultur nelayan rawai Kecamatan Bantan dalam mengelola dan memanfaatkan sumber daya perikanan yang tidak menda- pat pengakuan dari nelayan jaring batu; 2) faktor sosial yang cenderung melakukan perebutan wilayah tangkap, dimana kehadiran nelayan jaring batu telah dianggap mengganggu ketentraman dan kenyamanan nelayan rawai; dan 3) faktor yuridis yaitu keberadaan peraturan dan perundangan yang mengatur pemanfaatan sumber daya perikanan yang tidak sesuai dengan karakteristik daerah dan sistem nilai yang berlaku di masyarakat nelayan Kecamatan Bantan.

Perbedaan cara pandang terhadap sumberdaya perikanan oleh nelayan rawai Kecamatan Bantan dan pengusaha jaring batu disajikan pada Gambar 3. Konflik pemanfaatan tim- 
bul karena beberapa pengguna berkompetisi menggunakan sumber daya yang sama dalam ruang laut yang sama dan menerapkan kegiatan-kegiatan yang memanfaatkan sumber daya tidak sesuai antara satu dengan yang lain (Dahuri et al., 1996). Intensitas konflik akan ditentukan oleh tingkat perbedaan teknologi penangkapan yang digunakan nelayan, keterbatasan teritorial distribusi spesies yang akan ditangkap dan jumlah nelayan yang memperebutkannya (Kusnadi, 2002).

Wujud konflik antar nelayan juga ditimbulkan oleh adanya perbedaan nilai, kepentingan dan konflik di kalangan mereka yang berada dalam posisi yang sama. Misalnya konflik antara alat tangkap rawai dan jaring batu, rawai menggunakan teknologi yang sederhana serta kebutuhan modal yang rendah dan nelayan yang mengoperasikan rawai relatif lebih dominan sedangkan jaring batu menggunakan teknologi yang lebih tinggi dan membutuhkan modal yang lebih besar. Konsekuensinya, kedua alat tangkap ini digunakan oleh nelayan dengan tingkat sosial yang berbeda. Hal inilah yang diduga sebagai awal mula terjadinya konflik.

Faktor sosial lainnya yang ikut mendorong konflik antara nelayan rawai dan jaring batu yaitu adanya persaingan antara kedua kelompok nelayan untuk memperoleh objek yang sama di wilayah tangkap yang sama pula. Perbedaan bentuk dan sifat alat tangkap membuat kedua alat tangkap memiliki laju tangkap yang berbeda pula. Jaring batu dengan konstruksi yang mampu menyapu area tangkap yang lebih luas, memiliki laju tangkap yang lebih tinggi dibanding rawai, sehingga jaring batu akan mendapatkan hasil yang lebih banyak dibanding rawai.

Kemampuan alat tangkap yang rendah dan semakin banyaknya nelayan jaring batu yang beroperasi mengakibatkan semakin kecilnya peluang nelayan rawai dalam mendapatkan spesies target yaitu ikan kurau. Semakin kecilnya peluang untuk mendapatkan ikan akan berakibat semakin kecil pula pendapatan yang mereka dapatkan. Kondisi tersebut tentu saja mendesak perekonomian rumah tangga sehingga memicu kemarahan nelayan rawai kepada nelayan jaring batu.

Wujud konflik antar nelayan juga ditimbulkan karena perbedaan nilai, kepentingan dan konflik dikalangan mereka yang berada dalam posisi yang sama. Wilayah penangkapan nelayan di Kecamatan Bantan bukanlah perairan laut yang luas, dalam arti disemua wilayah laut dapat melakukan aktifitas penangkapan. Karakteristik geografis dasar perairan yang landai menyebabkan ruang tang- kapan ikan menjadi sempit. Keterbatasan ruang tangkap ini memaksa para nelayan berada pada ruang yang sama sehingga terjadi tumpang tindih atau penumpukan alat tangkap yang akan memicu konflik.

Dampak yang ditimbulkan karena persengketaan antara nelayan rawai dengan jaring batu telah memicu hubungan yang tidak harmonis antara nelayan rawai dengan pihak-pihak lain, seperti dinas perikanan (kabupaten dan provinsi), aparat kepolisian dan Angkatan Laut (konflik sekunder). Konflik sekunder ini terjadi akibat ketidakpuasan nelayan rawai terhadap sikap dinas perikanan dan aparat sebagai pihak yang berwenang dianggap tidak sungguhsungguh dalam penyelesaian kasus dan selalu berpihak pada nelayan jaring batu, sehingga menimbulkan kecurigaan.

Konsepsi yang berlanjut pada eksploitasi sumber daya perikanan oleh nelayan jaring batu telah melanggar tatanan sosial yang berlaku di wilayah penangkapan nelayan rawai. Nelayan rawai menganggap jaring batu merupakan alat tangkap yang berpotensi mengancam kelestarian sumber daya perikanan. Anggapan negatif ini terbukti ketika jaring batu bebas beroperasi, dapat dipastikan nelayan perairan Bengkalis khususnya nelayan rawai tidak mendapatkan ikan selama beberapa hari. Nelayan jaring batu merupakan nelayan buruh yang dimodali oleh para pengusaha perikanan tangkap berorientasi pada jumlah hasil tangkapan yang mengacu pada prinsip-prinsip ekonomi yang mengandalkan teknologi. Prinsip mereka adalah menggunakan teknologi penangkapan yang lebih modern untuk mendapatkan hasil tangkapan sebanyak-banyaknya.

Perbedaan ideologi dan prinsip terjadi dalam pemanfaatan sumber daya perikanan antara nelayan rawai Kecamatan Bantan dengan nelayan jaring batu yang datang dari luar. Keduanya mengartikulasikan dan memperlakukan sumber daya perikanan secara berbeda. Nelayan rawai menerapkan pemanfaatan sumber daya perikanan berbasis lokal yang bersifat konservasi sedangkan nelayan jaring batu mengaktualisasikan kepentingannya berdasarkan aspek ekonomi dan modal yang bersifat ekploitatif. Dikotomi dan polarisasi semacam inilah yang menggambarkan tajamnya persoalan etnosentrisme yang kental mengiringi modernisasi (Hettne, 2001), sehingga berpotensi terjadi konflik.

Konflik yang terjadi di perairan Bengkalis dapat diselesaikan dengan beberapa cara, diantaranya: 1) melakukan mekanisme pengaturan yang sistematis terhadap pemanfaatan sumberdaya ikan; 2) meningkatkan pengawasan 


\section{NELAYAN}

RAWAI

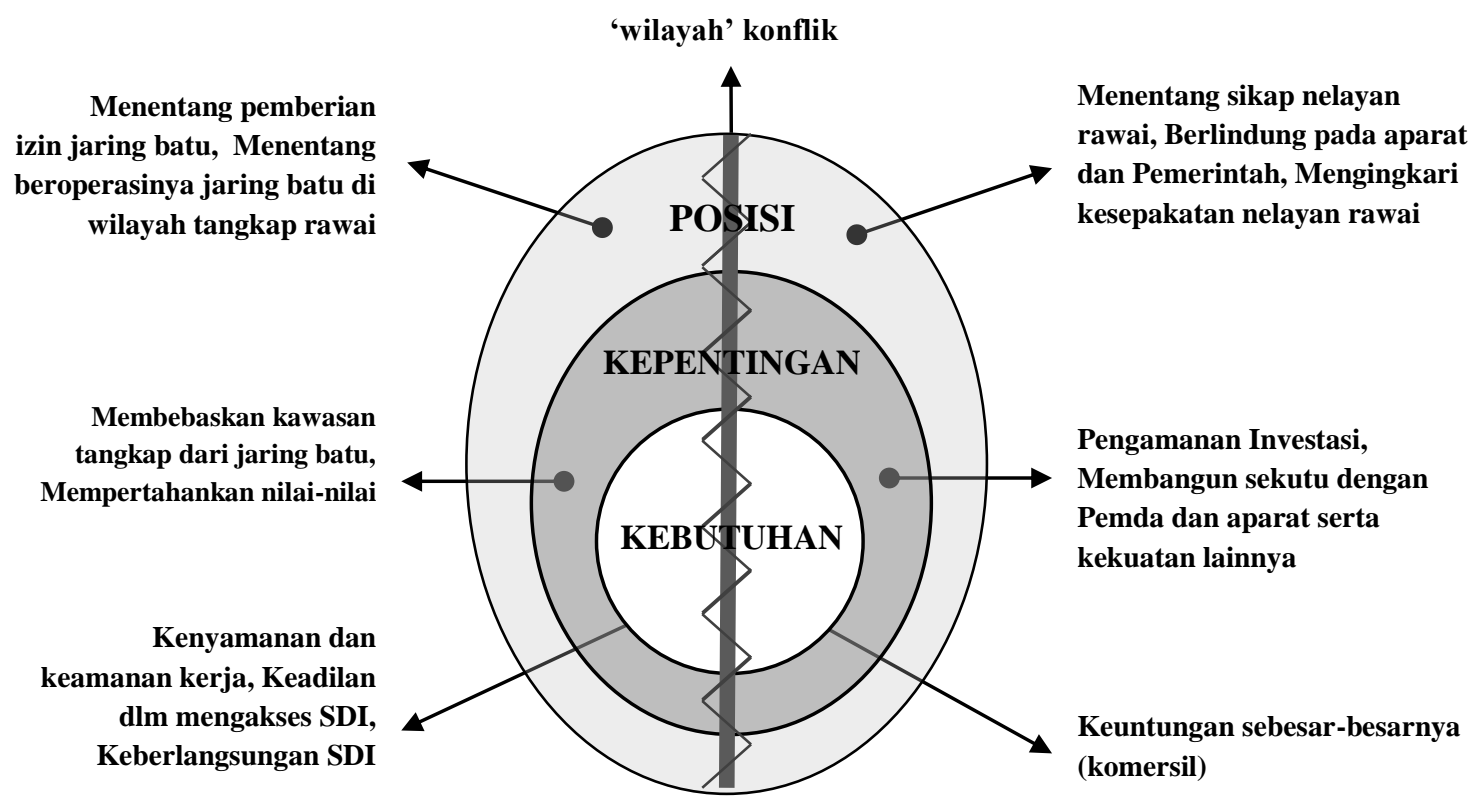

PENGUSAHA

JARING BATU

\section{Gambar 3 Analogi “Bawang Bombay” konflik nelayan rawai Kecamatan Bantan dengan} nelayan jaring batu.

terhadap pemanfaatan sumber daya ikan dari alat tangkap yang dapat menimbulkan konflik dan dapat memberikan jaminan keamanan dalam melakukan usaha penangkapan, sehingga dapat meningkatkan pendapatan nelayan; 3) mengakui secara formal hak ulayat yang berlaku dimasyarakat nelayan dalam pemanfaatan dan pengelolaan sumber daya perikanan tangkap.

\section{KESIMPULAN}

\section{Kesimpulan}

Konflik yang terjadi di perairan Kabupaten Bengkalis dikarenakan perburuan terhadap ikan kurau meningkat. Wujud konflik antar nelayan juga ditimbulkan oleh adanya perbedaan nilai, kepentingan dan konflik dikalangan mereka yang berada dalam posisi yang sama. Modernisasi pada sektor perikanan tangkap telah terbukti memperbesar arus eksploitasi yang berujung pada kerusakan ekosistem laut dan over fishing serta kerawanan sosial antar nelayan akibat persaingan dalam pemanfaatan sumber daya perikanan. Penambahan jumlah nelayan dan alat tangkap yang beroperasi tidak sesuai dengan ketersediaan sumber daya perikanan. Berbedanya tingkat teknologi dan pemodalan yang digunakan antar alat tangkap, misalnya alat tangkap rawai dengan teknologi yang sederhana serta kebutuhan modal yang rendah dan nelayan yang mengoperasikan rawai relatif lebih dominan. Adapun jaring batu menggunakan teknologi yang lebih maju dan membutuhkan modal yang lebih besar. Sebagai konsekuensinya, kedua alat tangkap ini digunakan oleh nelayan dengan tingkat sosial yang berbeda. Hal inilah yang diduga sebagai awal mula terjadinya konflik.

\section{Saran}

Penyelesaian konflik di perairan Kabupaten Bengkalis dapat dilakukan dengan membuat kebijakan pemerintah yang tegas untuk mengatur penggunaan alat tangkap dalam pengelolaan dan pemanfaatan sumber daya perikanan yang memperhatikan kondisi wilayah dan sosial budaya masyarakat setempat. Perlu juga dikembangkan sistem pengawasan masyarakat yang didukung oleh aturan legal untuk mencegah agar tidak terjadi pelangaran.

Celah yang ada untuk merealisasikan gagasan penyelesaian ini adalah mengusulkan Peraturan Daerah untuk mengatur dan menata pengelolaan dan pemanfaatan sumber daya perikanan yang sinergi antara kebijakan pemerintah Kabupaten Bengkalis dan Propinsi Riau serta memasukkan nilai-nilai yang berkembang di tengah masyarakat ke dalam Peraturan Daerah. 


\section{DAFTAR PUSTAKA}

Dahuri, R., Rais, J., Ginting, S.P., dan Sitepu. M.J. 1996. Pengelolaan Sumber Daya Pesisir dan Lautan Secara Terpadu (Integrated Coastal and Marine Resource Management). PT. Paradnya Paramita, Jakarta.

Charles AT, 2001. Sustainable Fisheries System. Fish and Aquatic resources series. Blackwell Science. Osney Mead, OXFORD OX2 OEL, UK. 370p
Fisher S., Jawed L., Steve W., Dekha I. A., Richard S. dan Sue W. 2001. Mengelola Konflik, Ketrampilan dan Strategi untuk Bertindak. The British Council Indonesia. Jakarta.

Hettne, B. 2001. Pembangunan Dunia Ketiga. (ed) A. Puspo Kuntjoro, Gramedia Pustaka Utama. Jakarta.

Kusnadi. 2002. Konflik Sosial Nelayan, Kemiskinan dan Perebutan Sumber daya Perikanan. LKIS. Yogyakarta. 